\title{
Identification of Forcing Mechanisms of Convective Initiation over Mountains through High-Resolution Numerical Simulations
}

\author{
Zuohao $\mathrm{CAO}^{* 1}$ and Huaqing $\mathrm{CAI}^{2}$ \\ ${ }^{1}$ Environment and Climate Change Canada, Toronto, Ontario, Canada \\ ${ }^{2}$ U.S. Army Research Laboratory, White Sands Missile Range, New Mexico, USA
}

\begin{abstract}
Citation: Cao, Z. H., and H. Q. Cai, 2016: Identification of forcing mechanisms of convective initiation over mountains through high-resolution numerical simulations. Adv. Atmos. Sci., 33(10), 1104-1105, doi: 10.1007/ s00376-016-6198-4.
\end{abstract}

Convection and its ensuing severe weather, such as heavy rainfall, hail, tornado, and high wind, have significant impacts on our society and economy (e.g., Cao et al., 2004; Fritsch and Carbone, 2004; Verbout et al., 2006; Ashley and Black, 2008; Cao, 2008; Cao and Ma, 2009; Zhang et al., 2014). Due to its localized and transient nature, the initiation of convection or convective initiation remains one of the least understood aspects of convection in the scientific communities, and it is a significant challenge to accurately predict the exact timing and location of convective initiation (e.g., Cai et al., 2006; Wilson and Roberts, 2006; Xue and Martin, 2006; Cao and Zhang, 2016).

Convective initiation can be attributed to various forcing mechanisms, including, but not limited to, upper-level forcing, boundary-layer forcing, and a combination of them (e.g., Bennett et al., 2006; Lopez, 2007; Marsham et al., 2011). For surface-based convective initiation, boundary-layer forcing often determines the precise location where convection is triggered within large areas of potential instability (e.g., Pielke, 2001). The most common boundary-layer triggering mechanisms include surface fronts, drylines, gust fronts, sea/lake land breezes, orographic circulations, and boundary layer horizontal convective rolls. In addition, inhomogeneity in land surface characteristics can also produce sufficient vertical motion to force convection, particularly under strong surface heating conditions (Trier et al., 2004).

Various possible mechanisms for convective initiation are generally recognized, but the exact forcings responsible for a specific case are often difficult to ascertain, especially when multiple physical processes and their interactions are involved.

In this issue (Page 1120-1136), Wang et al. (2016) devote themselves to the understanding of the physical mechanisms responsible for convective initiation over the Dabie Mountains located in eastern China. By performing numerical simulations and sensitivity experiments for a real case associated with weak synoptic flows of Meiyu front, the

\footnotetext{
* Corresponding author: Zuohao CAO

Email: zuohao.cao@canada.ca
}

authors analyze the physical processes that create nearsurface convergence and lead to initiation of convection over this complex mesoscale mountain. Their analyses reveal three mountain-related processes that are responsible for the nearsurface convergence forcing and subsequent convective initiation over the Dabie Mountains: (1) thermally-driven upslope winds that converge over the mountain ridge and peaks, (2) dynamically-driven flows around the mountain peaks and their convergence on the lee side of the peaks, and (3) valleyenhanced upslope winds (due to thermal and dynamic channeling effects) generating additional convergence between the mountain peaks. Furthermore, they examine the interactions among thermally-driven winds, the dynamically-driven flows, and the mountains, which contribute to the development of convective clouds and precipitation. This study provides clear, new insights on the convective initiation processes over the Dabie Mountain region, which is known to be a source of many precipitation systems in eastern China.

In recent years, the international meteorological communities have made substantial efforts in conducting field campaigns to help improve the understanding of convective initiation and quantitative precipitation forecast (QPF) (e.g., Weckwerth and Parsons, 2006; Browning et al., 2007; Wulfmeyer et al., 2008; Weckwerth et al., 2015). Different from field campaigns, the numerical simulation experiments carried out by Wang et al. (2016) are relatively inexpensive and flexible for examining physical mechanisms of convective initiation. The conceptual model based on their numerical simulations, which serves as a nice summary of their major findings, helps better understand the complex processes involved in the convection initiation in a mountainous region. Certainly, their work can be further extended to assess nonlinear interactions among the thermally-driven flows, dynamically-driven winds, the mountains, and synoptic environments (e.g., Meiyu front) through more sophisticated numerical experiments (e.g., Stein and Alpert, 1993; Cao, 2006). It is anticipated that in the future model simulation experiments may provide even more useful information for understanding convective initiation in mountainous areas, and may help improve the prediction skills of QPF through better treatment of physical processes in numerical models. 


\section{REFERENCES}

Ashley, W. S., and A. W. Black, 2008: Fatalities associated with nonconvective high-wind events in the United States. Journal of Applied Meteorology and Climatology, 47, 717-725, doi: 10.1175/2007JAMC1689.1.

Bennett, L. J., K. A. Browning, A. M. Blyth, D. J. Parker, and P. A. Clark, 2006: A review of the initiation of precipitating convection in the United Kingdom. Quart. J. Roy. Meteor. Soc., 132, 1001-1020.

Browning, K. A., and Coauthors, 2007: The convective storm initiation project. Bull. Amer. Meteor. Soc., 88, 1939-1955.

Cai, H. Q., W.-C. Lee, T. M. Weckwerth, C. Flamant, and H. V. Murphey, 2006: Observations of the 11 June dryline during IHOP_2002-A null case for convection initiation. Mon. Wea. Rev., 134, 336-354.

Cao, Z. H., 2006: Nowcasting for severe rainfall: A processbased dynamic-statistical approach. AGU 2006 Western Pacific Geophysics Meeting, Beijing, China, Preprint Volume.

Cao, Z. H., 2008: Severe hail frequency over Ontario, Canada: Recent trend and variability. Geophys. Res. Lett., 35, L14803, doi: 10.1029/2008GL034888.

Cao, Z. H., and J. M. Ma, 2009: Summer severe-rainfall frequency trend and variability over Ontario, Canada. Journal of Applied Meteorology and Climatology, 48, 1955-1960.

Cao, Z. H., and D.-L. Zhang, 2016: Analysis of missed summer severe rainfall forecasts. Wea. Forecasting, 31, 433-450.

Cao, Z. H., P. Pellerin, and H. Ritchie, 2004: Verification of mesoscale modeling for the severe rainfall event over southern Ontario in May 2000. Geophys. Res. Lett., 31, L23108, doi: 10.1029/2004GL020547.

Fritsch, J. M., and R. E. Carbone, 2004: Improving quantitative precipitation forecasts in the warm season: A USWRP research and development strategy. Bull. Amer. Meter. Soc., 85, 955-965.

Lopez, P., 2007: Cloud and precipitation parameterizations in modeling and variational data assimilation: A review. $J$. Atmos. Sci., 64, 3766-3784.

Marsham, J. H., S. B. Trier, T. M. Weckwerth, and J. W. Wilson, 2011: Observations of elevated convection initiation leading to a surface-based squall line during 13 June IHOP_2002. Mon. Wea. Rev., 139, 247-271.
Pielke, R. A., 2001: Influence of the spatial distribution of vegetation and soils on the prediction of cumulus convective rainfall. Rev. Geophys., 39, 151-177.

Stein, U., and P. Alpert, 1993: Factor separation in numerical simulations. J. Atmos. Sci., 50, 2107-2115.

Trier, S. B., F. Chen, and K. W. Manning, 2004: A study of convection initiation in a mesoscale model using high-resolution land surface initial conditions. Mon. Wea. Rev., 132, 2954 2976.

Verbout, S. M., H. E. Brooks, L. M. Leslie, and D. M. Schultz, 2006: Evolution of the U.S. tornado database: 1954-2003. Wea. Forecasting, 21, 86-93.

Wang, Q. W., M. Xue, and Z. M. Tan, 2016: Convective initiation by topographically induced convergence forcing over the Dabie Mountains on 24 June 2010. Adv. Atmos. Sci., 33(10), doi: 10.1007/s00376-016-6024-z.

Weckwerth, T. M., and D. B. Parsons, 2006: A review of convection initiation and motivation for IHOP_2002. Mon. Wea. Rev., 134, 5-22.

Weckwerth, T. M., B. Geerts, D. B. Parsons, and C. Ziegler, 2015: PECAN: Plains elevated convection at night: overview and first impressions. 37th Conference on Radar Meteorology, Norman, OK, USA, American Meteorological Society.

Wilson, J. W., and R. D. Roberts, 2006: Summary of convective storm initiation and evolution during IHOP: Observational and modeling perspective. Mon. Wea. Rev., 134, 23-47.

Wulfmeyer, V., and Coauthors, 2008: Research campaign: The convective and orographically induced precipitation study: A research and development project of the World Weather Research Program for improving quantitative precipitation forecasting in low-mountain regions. Bull. Amer. Meter. Soc., 89, $1477-1486$

Xue, M., and W. J. Martin, 2006: A high-resolution modeling study of the 24 May 2002 dryline case during IHOP. Part I: Numerical simulation and general evolution of the dryline and convection. Mon. Wea. Rev., 134, 149-171.

Zhang, D.-L., Z. H. Cao, J. M. Ma, and A. M. Wu, 2014: Summer nonconvective severe wind frequency over Ontario and its correlation with tropical Pacific sea surface temperature. Journal of Applied Meteorology and Climatology, 53, 1170 1182. 